\title{
Perspectives on gender parity in bioanalysis: an interview with Katryn Allen
}

Katryn Allen*,1

${ }^{1}$ PRA Health Sciences Bioanalytical Laboratory, 11070 Strang Line Rd, Lenexa, KS 66215, USA

*Author for correspondence: AllenKaty@prahs.com

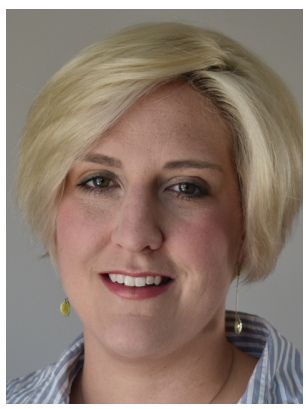

\section{Biography:}

Katryn Allen is currently a method development scientist at the PRA Health Sciences Bioanalytical Laboratory in Lenexa, Kansas. Katryn has over 5 years of pharmaceutical industry experience in bioanalytical method development and in the preclinical environment. While at PRA, she has developed ligand-binding assays for pharmacokinetic, pharmacodynamics and immunogenicity end points. She received her PhD in toxicology from the University of Kansas Medical Centre (KS, USA) in 2011.

Accepted for publication: 5 March 2019; Published online: 18 April 2019

What advice would you give to young women hoping to embark on a career in the field?

Remove the words "I'm sorry" from your vocabulary. Saying you are sorry in the work force and in the scientific world, indicates a weakness. I am not sure why.

Listen to those around you and rarely, if ever, will you hear men, or women in higher positions say "I'm sorry." They will admit when they are wrong, or even ask for forgiveness; but you will not hear them say "I'm sorry."

\section{What advice would you give to women hoping to pursue senior-level scientific positions?}

Speak up when you know the solution, suggest changes when they are needed, let people know when they are doing a good job, engage in discussions and do not be shy about taking credit.

\section{What do you see as being the most effective solution to getting more women involved in STEM careers?}

We need to encourage girls/women to take risks and get involved. I think often girls are more risk adverse when it comes to applying for fellowships or getting involved in clubs or groups. We need to let the girls and women around us know when these types of opportunities are available and encourage them to apply or show up. Starting to develop the communities which go along with internships and clubs at a young age is such a huge advantage later. We need to make sure the girls around us do not miss out.

\section{What are the main motivations for you in the industry as a woman?}

Right now, as a woman I want to break the glass ceiling. In my current position, I have five women as my counterparts in the USA. and my direct boss is a woman. However, after that it is all men. While I think that in my current position we have nearly achieved gender parity, when you look at our company globally that is not the case as you move higher. The women I work with are just as talented as the men and we all deserve a shot to move up, but we need more women in high positions to start paving the way for others.

\section{How did you overcome obstacles in your scientific career? Can you share any useful information others can use in their own careers?}

The biggest obstacle in my career so far has been that my first job out of academia was not the right fit. I am a hands-on person who loves to troubleshoot and the job was very hands off and required very little troubleshooting. 
It took a long time for me to realize that just because I have the credentials for a job, and many of my friends are successful in similar jobs, does not mean that it should be my job.

I would advise others to really think about their strengths as they look for positions, then during interview ask what a typical day is like. If your strengths and the day-to-day of the job do not match be honest with yourself. Also, talk to as many people as you can about what they do every day, do not just go off their title. It took working side-by-side with someone in the bioanalytical field for me to realize what a great fit method development could be for me.

\section{How important it is to have a short-term \& long-term goals in your career?}

I was never good at setting goals while I was in school. However, I found that having and sharing goals in industry has been critical. This is not because I now have a new outlook or motivation to achieve but rather because it has helped me communicate with my superiors. Clearly communicating to your superiors that you would like to one day be a director, or that you would like to try and implement a new process is imperative to being successful. Most companies have their employees set goals with their manager each year. Take this opportunity to communicate your long-term goal to your superior. Then get your managers advises on the short-term goals they think will help you achieve your long-term goal. Goal setting with your manager also means that they too are invested in the process. I have also found that by telling my superiors that my goal is to 'move up' they let me know about different opportunities as they arise. This was not happening until I spoke up and told them what I was looking for in my career.

Disclaimer

The opinions expressed in this interview are those of the interviewee and do not necessarily reflect the views of Future Science Group.

Financial \& competing interests disclosure

The author has no relevant affiliations or financial involvement with any organization or entity with a financial interest in or financial conflict with the subject matter or materials discussed in the manuscript. This includes employment, consultancies, honoraria, stock ownership or options, expert testimony, grants or patents received or pending, or royalties.

No writing assistance was utilized in the production of this manuscript. 